\title{
A MULTIFUNKCIONÁLIS HALGAZDASÁGOK SZEREPE ÉS JELENTŐSÉGE
}

\author{
Bozánné Békefi Emese - Gyalog Gergő - Váradi László
}

\begin{abstract}
Absztrakt: A vidéki gazdaság részét képező tógazdaságok amellett, hogy halat állítanak elö, értékes vízi élőhelyként működnek, hozzájárulnak az ökoszisztéma minöségének megörzéséhez és gazdagításához, fontos szerepet játszanak a vízgazdálkodásban és a tájkép formálásában, szolgáltatásokat nyújtanak a különbözö szabadidös tevékenységek számára, és hozzájárulnak a kulturális értékek megőrzéséhez. A multifunkcionális halgazdaságok müködésével kapcsolatos magyarországi tapasztalatok egyértelmüen azt mutatják, hogy a halgazdálkodás tevékenységeinek diverzifikálása jó lehetőséget jelent a fenntartható tógazdálkodás fejlesztésére. Szükség van azonban a multifunkcionális halgazdálkodás sajátosságainak, illetve a különböző funkciók közötti összefüggések jobb megértésére, amelyek jól meghatározott kutatási programokat igényelnek. A multifunkcionális tógazdaságok jelentős mértékben hozzájárulhatnak a vidéken élök megélhetésének javításához, a biológiai sokféleség fenntartásához és erōsítéséhez, ha a multifunkcionális tógazdaságok társadalmi és környezeti hasznát jobban elismerik és támogatják.
\end{abstract}

\begin{abstract}
Pond fish farms, which are a part of the rural economy, besides producing fish function as valuable aquatic habitat, contribute to the maintenance and enrichment of the quality of the ecosystem, play an important role in water and landscape management, provide services for various recreational activities, and contribute to the preservation of the cultural heritage. The experiences with the operation of multifunctional fish farms clearly showed that the diversification of activities is a promising alternative during the development of sustainable pond fish farming in Hungary. There is a need however for better understanding of the specificities of multifunctional pond fish farming and the inter-linkages between various functions which requires well-defined research programs. Multifunctional pond fish farms can contribute significantly to the improvement of rural livelihood and the maintenance and enhancement of biodiversification if the social and environmental benefits of multifunctional pond fish farms are well acknowledged and supported.
\end{abstract}

Kulcsszavak: multifunkcionalitás, fenntarthatóság, tógazdasági haltermelés

Keywords: multifunctionality, sustainability, pond fish farming

\section{Bevezetés}

A hazai haltermelés elsősorban tógazdaságokban, extenzív, illetve fél-intenzív módon, hagyományos technológiák alkalmazásával történik. A hazai tógazdálkodás más mezőgazdasági tevékenységekkel összehasonlítva nagyobb szerepet játszik a természeti környezetben, hiszen a halastavak mint vizes élöhelyek jelentősen hozzájárulnak a biodiverzitás megőrzéséhez és gazdagításához. A halastavak többcélú hasznosításának, illetve multifunkcionalitásának jelentősége az utóbbi évtizedekben került a figyelem középpontjába. A hazai tógazdálkodás felismerte a vizes élőhelyek megörzésében, illetve a vízi erőforrások hasznosításában meglévő felelősségét és a fejlesztési programok nem a termelés egyoldalú növelésére, hanem a multifunkcionalitásban rejlö lehetőségek kihasználására irányulnak. A multifunkcionális tógazdálkodás lényege, hogy adott természeti, illetve vízi erőforrásokat komplex módon hasznosít, tehát amellett, hogy a haltermelés meghatározó a hasznosításban, a természeti környezetet, az ökoszisztémát szolgáló tevékenységeket, illetve turisztikai és egyéb szolgáltatásokat is végez. 


\section{A halászati ágazat bemutatása}

A magyar halászati ágazat éves bruttó termelési értékének a 45\%-át a tógazdasági étkezési haltermelés adja. A hazai állattenyésztés bruttó termelési értékének mintegy 2,5\%-át és a hazai összes mezőgazdasági termelésnek megközelítőleg 1\%-át a halgazdálkodás teszi ki. A termék kibocsátáshoz, illetve a bruttó termelési értékhez való hozzájárulás alapján a halászati ágazat nemzetgazdasági súlya igen kicsinek tünhet, azonban éppen multifunkcionális szerepéből következően a nem termelési jellegü funkciók értékét figyelembe véve fontos eleme a nemzetgazdaságnak (Szücs-Szöllösi, 2014). A hazai 28000 hektár halastóból 2015-ben 24800 ha tóterületen, folyt olyan tevékenység, amely egyik alapvető eleme a haltermelés, de a tevékenységnek fontos szerepe van a vizes élőhelyek minőségének megőrzésében és gazdagításában, a vízkészlet gazdálkodásban, illetve általában a vidéki lakosság életkörülményeinek javításában.

A hazai haltermelés kb. 83\%-ban tógazdasági haltermelést jelent és kb. 17\%-ban intenzív, medencés haltermelést. Magyarország 2015. évi összes haltermelése 23610 tonna, a tógazdasági haltermelés 19900 tonna, amelyből az étkezési célú haltermelés 14300 tonna volt (a különbség az anyaállomány neveléséböl, és a következő év népesítő anyagának továbbneveléséből adódik). A halastavi termelés Magyarországon túlnyomórészt a ponty felnevelésére irányul, az éves haltermelésünkből több év átlagában mintegy $62 \%$-kal részesedik a ponty. A termelésben kisebb volumennel jelen van a fehér és pettyes busa, az amur, egyes ragadozófajok, mint a csuka, a lesőharcsa és a süllö. (AKI, 2016).

A hazai halászati ágazat fejlesztésének legfontosabb célja a hazai halfogyasztás növelése. Annak ellenére, hogy a halfogyasztásban évek óta kismértékü de folyamatos emelkedés figyelhető meg annak mértéke mindössze évi 5-6 kg/fö (az import tengeri hallal együtt), ezzel szemben az Európai Unióban az átlagos éves halfogyasztás egy före vetítve 25,8 kilogramm (EUMOFA, 2017). Nagy kihívás az ágazat számára, hogy a haltermékek növekvő importja ellenére folyamatosan ellássa a lakosságot egészséges, friss és élelmiszerbiztonsági elöirásoknak maradéktalanul megfelelő hazai haltermékekkel. A halászati ágazat fejlesztésének másik fő célja a horgászati igények kielégítése hazai termelésü, öshonos halfajokkal. Az ágazat fenntarthatóságát és fejlődését segíti elő a tógazdaságok multifunkcionális adottságainak jobb kihasználása, például turisztikai szolgáltatások révén.

\section{A multifunkcionális tógazdálkodás jelentősége}

$\mathrm{Az}$ utóbbi évtizedekben megváltoztak a tógazdálkodás gazdasági és társadalmi körülményei. A haltermékek piacán egyre nagyobb arányban jelennek meg a változatos formában feldolgozott import termékek és egyre nehezebb a hagyományos tavi halfajok élve történő értékesítése, bár a hagyományok miatt az élőhal forgalmazás még mindig jelentős hazánkban. A fogyasztói és piaci elvárások tehát a tógazdasági technológiák fejlesztését (pl. új fajok termelésbe vonását), illetve a feldolgozottság növelését igényli. A társadalmi elvárások ugyanakkor a természeti környezet, és a vízi erőforrások védelmét is magukban foglalják. Növekvő az igény 
a vízhez kötődő szabadidős tevékenységek iránt is, amelyben a tógazdaságok is szerepet játszanak.

A változó gazdasági és társadalmi igényekhez való igazodást azonban segíti az a körülmény, hogy a tógazdálkodás magában foglalja az alábbi funkciókat (Váradi, 2007):

- haltermelés;

- természeti szolgáltatások (pl. biodiverzitás megőrzés);

- környezeti szolgáltatások (pl. elfolyóvizek kezelése);

- vidéki lakosság foglalkoztatása (Oláh, 2001);

- turisztikai szolgáltatások (pl. horgásztatás, vendéglátás);

- hozzájárulás a térségi vízgazdálkodáshoz;

- hozzájárulás a tájkép formáláshoz;

- hagyományőrzés.

A fenti funkciók alapvetően az ökoszisztémák és az általuk biztosított ökoszisztéma szolgáltatások elemei. Ökoszisztéma szolgáltatások alatt azokat a hasznokat értjük, amelyeket az emberek az ökoszisztémákból megszereznek (MEA, 2003), azaz azon természeti javakat és szolgáltatásokat, melyeket az emberek életük során közvetlenül vagy közvetve felhasználnak. A természetes ökoszisztémák szolgáltatásainak értékelésére vonatkozó kutatások néhány évtizedes múltra tekintenek vissza, az agro-ökoszisztémákról azonban csak kevés ilyen jellegü információ áll rendelkezésre. Lengyel kutatók átfogó vizsgálatainak eredménye szerint egy extenzív, illetve egy félintenzív halastó termelési funkciójának értéke átlagosan $4830 \mathrm{Euro} / \mathrm{ha} / \mathrm{e} v$, míg a nem termelési funkció értéke ezt több, mint tízszeresen meghaladóan 52857 Euro/ha/év (Turkowski-Lirski, 2011). A halastavi ökoszisztéma szolgáltatásokra vonatkozó részletes adatokkal sem rendelkezünk, így a szolgáltatások ökológiai szempontú számszerüsítése és pénzbeli értékben való kifejezése még nem történt meg hazai viszonylatban sem. A haltermelési szektor egészének és egyes szereplöinek számára is fontos, hogy feltárjuk és számszerúsítsük ezeket $\mathrm{a}$ hasznos szolgáltatásokat, hiszen ezen adatok alátámasztásával lehetőségük nyílhat anyagi kompenzációra vagy támogatásokra, elfogadtatva azt, hogy az egész társadalom számára esszenciális funkciókat biztosító területeket és gazdálkodási formát tartanak fenn. Mivel az ökoszisztéma szolgáltatásai túlnyomórészt nem piaci javak, illetve nincsenek oly módon számszerüsítve, hogy összehasonlíthatók lennének a gazdaság szolgáltatásaival vagy a megtermelt tőkével, ezért ezeket a politikai döntéshozatalkor igen kis súllyal veszik figyelembe.

A különbözö tógazdaságok természetesen különböző mértékben és eltérő szinten reprezentálják az egyes funkciókat, adottságaiknak megfelelően. A haltermelés mellett leginkább a horgásztatás és egyes a turizmushoz kapcsolt funkciók a legelterjedtebbek. A tógazdálkodás diverzifikálásának és a termelés mellett más funkciók tevékenységbe vonásának az elsődleges hajtóereje a gazdálkodás eredményességének megörzése, illetve növelése. A bevételi oldalon így a halértékesítés mellett megjelennek a szolgáltatások bevételei, és az ezekhez kötődő 
támogatások. Az 1. ábra egy hazai tógazdaság, a réti-majori Aranyponty Zrt. példáján jól mutatja a bevétel összetételének változását.

\section{1. ábra: A bevételek összetételének alakulása egy tógazdaságban a multifunkcionális gazdálkodás bevezetését követően}

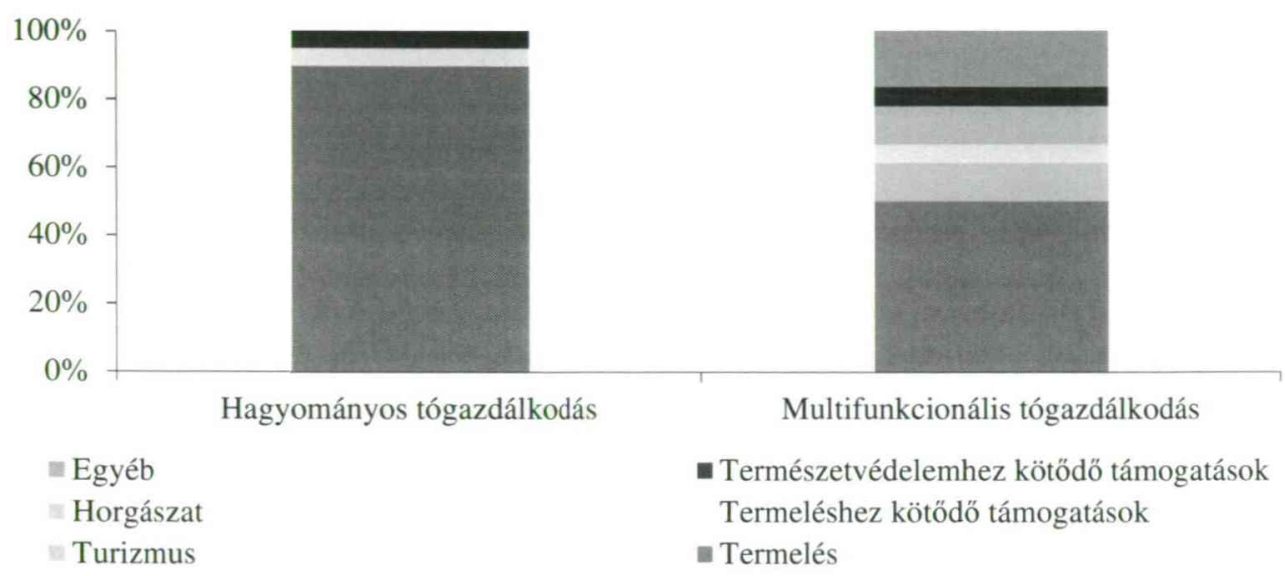

Forrás: A szerzők saját adatgyüjtése (2017)

A gazdaság összes bevétele a korábbi, hagyományos termelés központú gazdálkodáshoz viszonyítva átlagosan mintegy 35\%-kal nőtt, valamint annak nyereségtartalma is jelentősebb mértékủ. A multifunkcionális tógazdaságok, illetve általában ökoszisztéma szolgáltatásokat nyújtó extenzív tógazdaságok támogatásának ügye azonban továbbra sem megoldott.

A tógazdák már az ökonómiai optimum felett is vállalják a természeti környezet értékének megőrzését és növelését saját költségükre is, mint például a vízi- és vízparti növényzet fenntartása, a madarak és más víz környékén élő állatok életterének biztosítása, a felszíni vizek minőségének javítása. Megállapítható, hogy ma még nincsenek arányban a társadalmi elvárások és a társadalmi hozzájárulások, ami azt jelenti, hogy a tógazdaságok (elsősorban a multifunkcionális gazdaságok) viselnek olyan költségeket, amelyek a természeti értékek megőrzését és fejlesztését szolgálják.

\section{A multifunkcionális tógazdálkodás előnyei és hátrányai}

A hazai multifunkcionális tógazdaságok gazdálkodóinak elmúlt évtizedes tapasztalatai alapján néhány jelentős előny és hátrány az alábbiakban foglalható össze (Békefi-Váradi, 2007):

Előnyök:

- jobb gazdasági stabilitás és év közbeni likviditás a különböző mezőgazdasági tevékenységek miatt;

- különböző szolgáltatásokból (turizmus, horgásztatás) származó többletbevételek; 
- a bevételek nyereségtartalma magasabb;

- a környezetbarát gazdálkodáshoz nyújtott pénzügyi támogatáshoz való hozzáférés;

- lehetőség az ökológiai gazdálkodásra;

- a gazdaság jobb megjelenítése és társadalmi elfogadottsága.

Hátrányok:

- a multifunkcionális gazdaság létrehozása beruházásokat igényel;

- a komplex gazdálkodás menedzsmentje összetett feladat;

- a szolgáltatási tevékenység teljes mértékben eltér a halgazdálkodástól;

- a gazdaság méretének viszonylag nagynak kell lennie;

- a gazdaság vonzó természetes környezetben kell, hogy elhelyezkedjen.

\section{Következtetések}

A halastavi gazdálkodás a környezettudatos gazdálkodás erősítésével, a környezetkímélő, környezetbarát haltermelési módszerek alkalmazásán keresztül hozzájárul a természeti értékek fennmaradásához, a környezeti állapot javulásához. Ezért e módszerek fokozottabb ösztönzése a jövőre nézve továbbra is feladat. A tógazdálkodás fejlesztésének egyik iránya továbbra is a tevékenységek diverzifikálása, illetve multifunkcionalitásban rejlő lehetőségek kihasználása. A tógazdák innovációs készsége és fejlesztési törekvései mellet szükség van azonban a multifunkcionális gazdálkodás feltételeinek javítására, sajátosságainak, illetve a különböző funkciók közötti összefüggéseknek jobb megértésére, valamint a halastavi ökoszisztéma szolgáltatások pénzértékben történő kifejezésére, amelyek jól meghatározott kutatási programokat igényelnek.

\section{Irodalomjegyzék}

AKI - Agrárgazdasági Kutató Intézet (2016): Statisztikai jelentések, Lehalászás jelentés XXI. évfolyam

Békefi E., Váradi L (2007): Multifunctional pond fish farms in Hungary. Aquaculture International, 15: $227-233$.

EUMOFA - European Market Observatory for Fisheries and Aquaculture Products (2017): EU consumer habits regarding fishery and aquaculture products. Final Report, January 2017.

MEA, Millennium Ecosystem Assessment (2003): Ecosystems and Human Well-being: A Framework for Assessment. - Island Press, Washington DC.

Oláh J. (2001): Die Lage der ländlichen Entwiucklung in Ungarn am Beispiel der statistischen Planungsregion Nagykálló. 11. Jahrbuch der Österreichischen Gesellschaft für Agrarökonomie, 123-130.

Szücs I., Szöllösi L. (2014): Vertikális és horizontális integrációs lehetöségek a hazai haltermékpálya mentén. Az átalakuló, alkalmazkodó mezögazdaság és vidék: tanulmányok: XIV. Nemzetközi Tudományos Napok: Gyöngyös, 2014. március 27-28. 1401-1414.

Turkowski K., Lirski A. (2011): Non-productive functions of fish ponds and their possible economic evaluation. In: A. Lirski, A. Pyc (eds). Carp culture in Europe. Current status, problems, perspective. IRS Olsztyn, 25-42.

Váradi L. (2007): Extensive aquaculture in freshwater and its contribution to rural development. Paper presented at the Conference on European aquaculture and its opportunities for development. 15-16 November 2007, Brussels. 